\title{
Development of financial intermediation in a sustainable economy
}

\author{
Aleksey Mikryukov*, and Anna Serebrennikova \\ Ural State University of Economics, 8 Marta Str., 62, 620144 Ekaterinburg, Russia
}

\begin{abstract}
The article examines the theoretical and practical aspects of the development of financial intermediation in the context of sustainable economic development. Sustainable economic development has an impact on the life of the population and enterprises and leads to changes in their needs. Meeting the needs of the entire society is possible through the sustainable development of the financial market as a whole and its individual segments, including new areas of financial intermediation. Banks are considered one of the first financial intermediaries, but the steady development of the economy, accompanied by digitalization, leads to the emergence of new, alternative directions. One of them is crowdfunding. For credit institutions, crowdfunding is an opportunity to diversify their business, reduce lending risks, and expand their customer base. The article presents the dynamics of crowdfunding development in the Russian Federation and presents a comparative analysis of the main financial indicators of the largest Russian banks and crowdfunding platforms. The conclusion is made about the role of banks and alternative financing methods in a sustainable economy and their positive impact on the development of the real sector of the economy.
\end{abstract}

\section{Introduction}

Over the past decade, financial markets have undergone numerous changes due to the processes of globalization of the world economy, the consequences of the global financial crisis, and, above all, due to the tightening of regulatory influence, the increased burden on capital, as well as the rapid growth of fintech companies[5].In the strategic aspiration and priorities of sustainable economic development, the digital economy is considered as a powerful driving force that has activated the processes of digitalization in all areas of economic activity, where modern digital technologies and financial innovations based on them have determined the trends of innovation processes, including to a greater extent in the field of financial intermediation.

As a result, a new financial market has emerged, both within individual countries and the global financial market as a whole, creating conditions in which the emergence of alternative financial instruments is only a matter of time. In this regard, the study of the transformation of the banking system and how these transformational changes in the activities of banks are consistent with the existing theory of financial intermediation in the new economy is updated.In a stable economy, it is important to develop financial intermediation and its new areas, such as crowdfunding. Participants in financial 
intermediation can not only stabilize the financial sector of the economy, but also give an impetus to the development of the real sector and the service sector by providing new financial instruments.

\section{Materials and Methods}

The methodological basis of the study was a review of the works of domestic and foreign scientists on financial intermediation of credit institutions. To study crowdfunding as a tool for innovative financing, General scientific methods of cognition are applied: historical, analysis and synthesis, generalization.

\section{Results and Discussion}

Financial markets cannot exist without financial intermediaries, which are banks. The basis of the methodology of financial intermediation of credit organizations, in our opinion, is the research of J. Tobin and Y. Fama. In the views of J.Tobin, "...both borrowers and owners of available funds consider financial intermediaries, including commercial banks, as sources of alternative opportunities for obtaining loans or placing funds. The amount of funds placed on Bank deposits and subsequently participating in the creation of money is determined by the result of competition between financial intermediaries" [30]. Ideas Of J. Tobin were continued in the works of Professor J. Pham in the 1970s. He described the Bank as "...a mutual Fund accumulating various deposits" [28, p.26] and "...an investment Fund with a particularly low level of risk and low income" [28, p. 27].

Further questions of the nature and essence of financial intermediation were reflected in the works of both foreign and domestic scientists-economists (H. U. Derig, F. Mishkin, J. Sinki, S. M. Frost; O. I. Lavrushin, G. N. Beloglazova, N. I. Parusimov, S. S. Korneva, V. M. Usoskin, E. A. Pomogaev, I. D. Kotlyarov, etc.). In fact, each of the researchers of banking activity proceeds from the provisions of the Theory of financial intermediation, which is dominant in the economic literature, and uses as a subject of study the functions, goals and mechanisms of functioning of financial intermediaries.

Justifying the need for financial intermediaries and indirect financing, F. Mishkin notes that "...they significantly reduce operating costs by distributing risks and solving problems of incorrect choice and moral hazard, as well as facilitating the transfer of funds to organizations that have the opportunity to invest them in production " [9, P. 68].

S. M. Frost draws attention to the intermediary role of banks that transform short-term deposits (current accounts) into long-term loans, and considers it the most important[23, P.12].A similar opinion is held by Joseph Sinkey, Jr., who believes that "...the main activity of banks is to Finance loans from deposits. However, if earlier banks were considered exclusively as intermediaries in the distribution of Finance, at the current stage of economic development, they can be considered as companies that generate information and protect transactions." [25, C.25].

According to Russian scientists, such as V. Y. Belousov, I. O. Kozyr, V. M. Usoskin, financial intermediaries are considered as "...business agents specializing in the simultaneous purchase and sale of financial obligations" or as"... participants in commercial activities that connect lenders and borrowers, accepting deposits from the population and placing them in the form of business loans" [24, P. 15] and "...perform the functions of qualitative transformation of assets, which is primarily due to the discrepancy between the terms of assets and liabilities; asset conversion, taking into account the amount of funds used; maintaining the necessary level of liquidity in the financial system; transformation of assets to ensure their proper quality" [24, P. 15]. 
However, the functions of financial intermediation in the economic system are performed not only by banks, but also by investment companies, pension funds, insurance companies, registrars and depositories, and therefore, they, like banks, are carriers and savers of information and transmit this information to other market participants[10](figure $1)$.

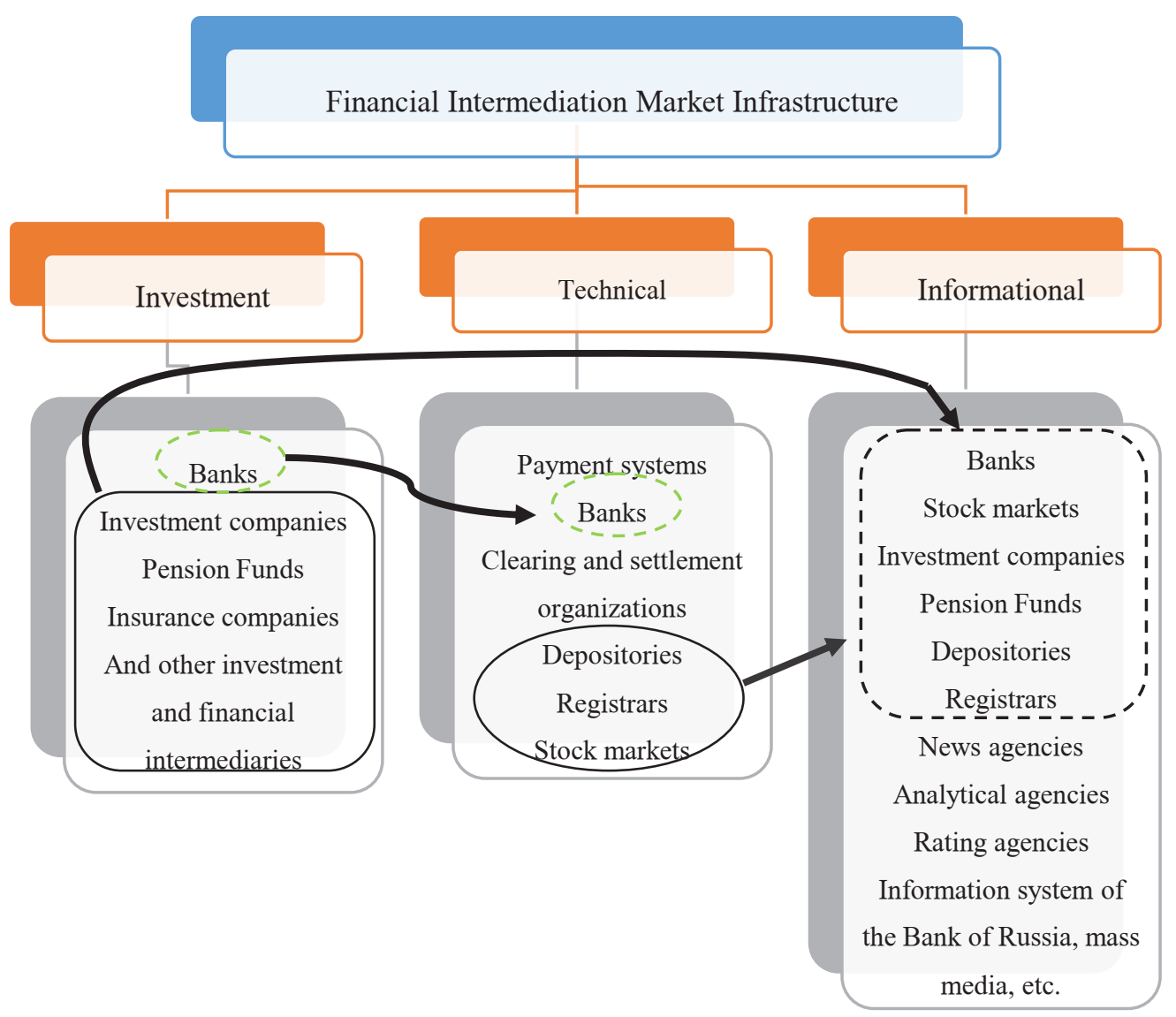

Fig.1 Infrastructure of the Financial Intermediation Market (compiled by the author according to [8, 26])

The existing infrastructure of the financial intermediation market is primarily focused on financing large and stable innovative projects. Projects of the new economy and industry 4.0 do not meet the standards of traditional financial institutions. These conditions dictate the requirements for the development and further development of new financing tools that ensure the implementation of innovative projects. Digitalization takes traditional financial intermediation to a new level (figure 2). 


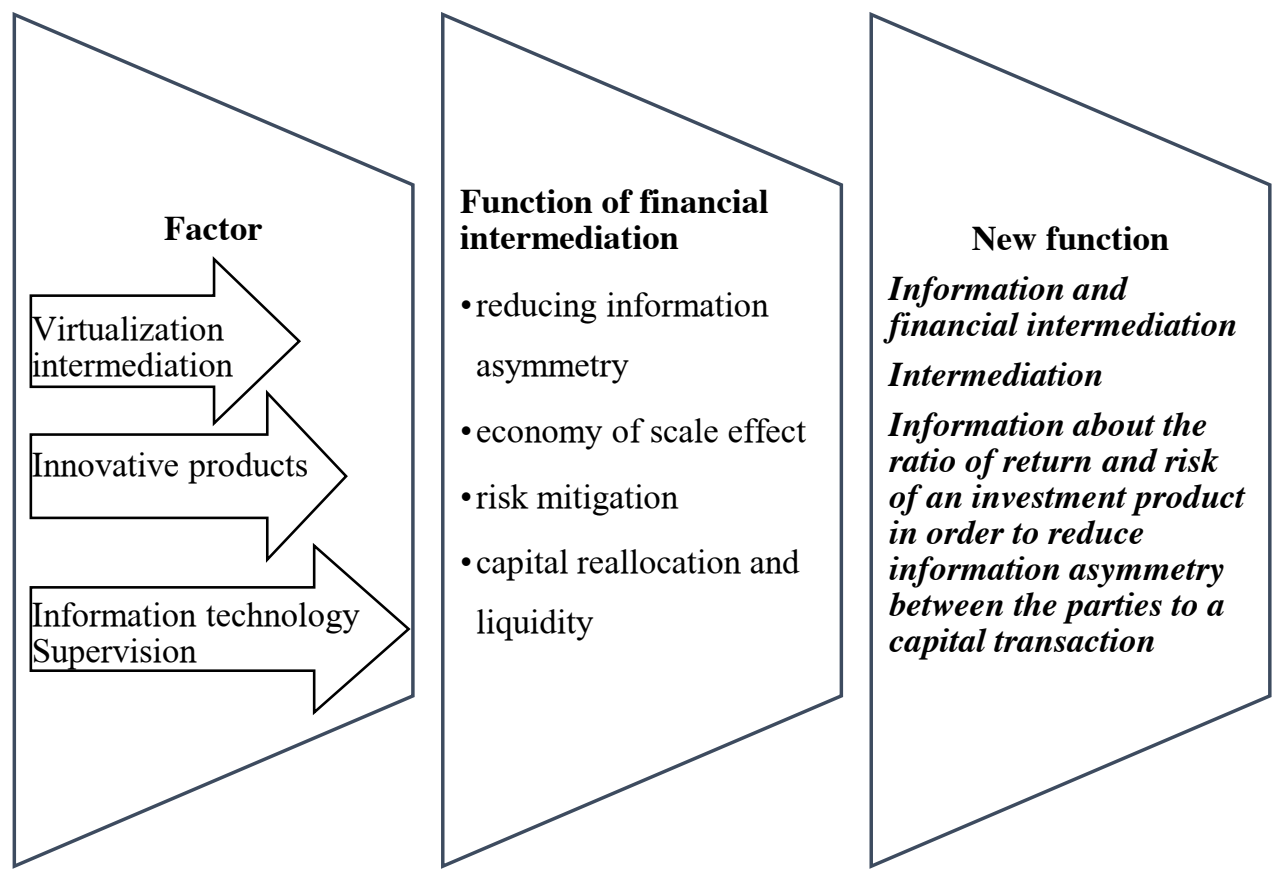

Fig. 2. Information transformation of modern banks (compiled by the author on $[10,16,18,19]$ )

Thanks to the new function, banks as intermediaries increase their influence both in the market of traditional financial products and in the market of information services. At the same time, the Bank, as an information and financial intermediary, helps to reduce the information risk for the lender, since it analyzes the borrower and provides the lender with information about the transaction risk.

Referring to statistical data, it can be stated that at the beginning of 2020, the number of Internet users in the world was 4.5 billion people, the audience of social networks - 3.8 billion people. Thus, $59 \%$ of the world's population is already online. In Russia, the number of Internet users is about 118 million people, i.e. $81 \%$ of the population [21]. The emergence of a networked society as a new form of social reality is associated with the use of the Internet for social interactions, which allowed us to look at the individual and society from a different perspective. Space virtualization creates forms of network communication that, as they develop, allow an increasing number of people to meet individual and social needs through interaction on the Internet.The spread of business models based on digital platforms gives an unprecedented boost to the development of banking intermediation [6].

In this regard, crowd technologies have been developed and applied, involving the use of personal resources to solve socially and socially significant tasks, the development and production of innovative and technological financial products, and the provision of social services [20]. Crowdfunding (translated from English means "financing an idea or project by a crowd of people or a community") is of particular interest among crowd technologies [17]. In a general sense, it is a technology of collective financing that allows the project to be implemented by attracting funds from a wide range of voluntary participants[3]. This process takes place on specialized Internet resources-crowdfunding platforms that can serve as information intermediaries (ensuring interaction of depositors with projects, transferring funds, without using their own accounts), and financial intermediaries (depositors ' funds are accumulated on the platform's accounts before getting into projects) $[4,7]$.

Crowdfunding technology is actively developing both abroad and in Russia. The US is one of the most advanced markets in the world when it comes to crowdfunding and 
alternative Finance. In 2017, the US accounted for $96.5 \%$ of total funding in the Americas. Second on the list after the United States is Canada with a market share of almost $2 \%$, more than all of Latin America and the Caribbean combined. Canada's crowdfunding market size of 867.6 million the volume of crowdfunding was higher than that of any country in mainland Europe, where France ranked first with 661.4 million euros or approximately 751.5 million us dollars, followed by Germany (595.4 million euros) and the Netherlands (279.9 million euros). In 2018, the volume of crowdfunding in Canada increased by $159.4 \%$, from $\$ 334.5$ million to $\$ 867.6$ million [29].

Analyzing the level of development of crowdfunding in Russia, it can be noted that it is at an early stage of development, since it is a relatively new and poorly studied phenomenon for Russian investors. But at the same time, according to the Bank of Russia, the total volume of the crowdfunding market in 2018 exceeded the mark of 15 billion rubles, a tenfold increase compared to 2015 (figure 3).in 2020, this segment, according to analysts, can overcome the mark of 20-22 billion rubles.

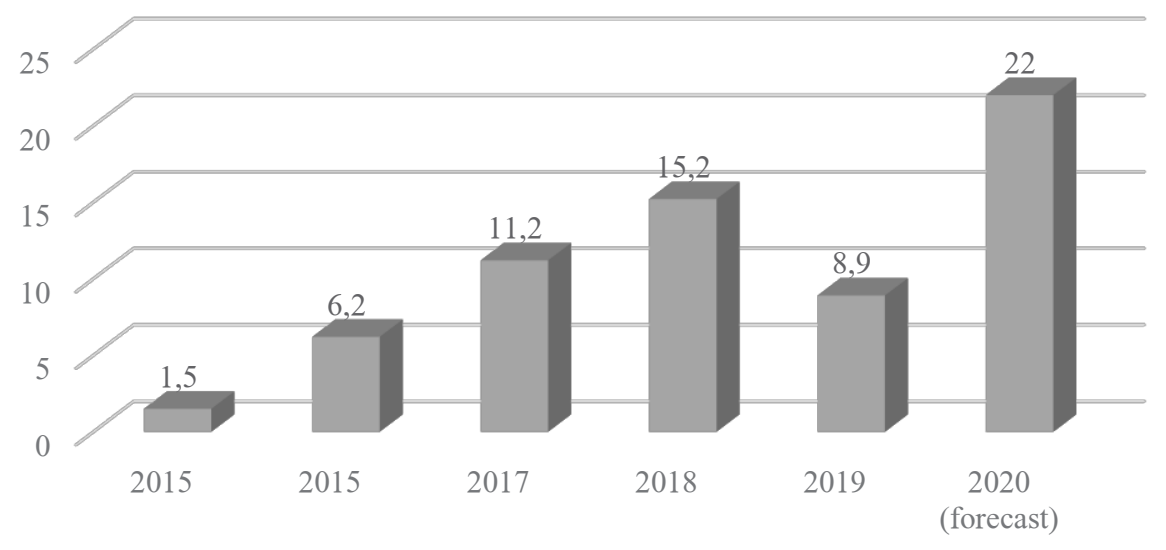

Fig.3.Dynamics of crowdfunding development in the Russian Federation in 2015-2019 (billion rubles) (calculated according to [12,27])

The advantages of alternative financing methods compared to traditional ones are undoubtedly obvious, and this is primarily due to their innovative characteristics due to the use of advanced digital technologies that allow applying new approaches to concluding transactions, namely: to conclude financial transactions online, without having to collect and submit a huge package of documents in person and with minimal risk; attracting investments from a wide range of non-professional investors in the most dynamically developing sectors of the economy; reduce transaction costs by simplifying the process of making transactions and conducting them through automated platforms; accurate assessment of the project's performance, which increases the chances of getting investment. The main goal of alternative financing methods is to revolutionize financial intermediation, create an alternative to outdated, inefficient, and untrusted banking, and replace it with a software platform that is honest, transparent, efficient, and creates fewer costs for borrowers and investors.

For comparison, here are the main financial indicators of the largest Russian banks and crowdfunding platforms for 2018-6 months of 2020. (table 1,2). 
Table 1.Financial indicators of the largest Russian banks for 2018-6 months of 2020(trln.RUB.)

\begin{tabular}{|c|c|c|c|c|c|c|c|c|c|}
\hline & \multicolumn{3}{|c|}{$\begin{array}{c}\text { Amount of Funds } \\
\text { Raised }\end{array}$} & \multicolumn{3}{c|}{$\begin{array}{c}\text { Size of the Loan } \\
\text { Portfolio }\end{array}$} & \multicolumn{3}{c|}{ Profit } \\
\cline { 2 - 10 } Bank & $\begin{array}{c}\mathbf{2 0 1} \\
\mathbf{8}\end{array}$ & $\mathbf{2 0 1 9}$ & $\begin{array}{c}\mathbf{6} \\
\text { months } \\
\mathbf{2 0 2 0}\end{array}$ & $\mathbf{2 0 1 8}$ & $\mathbf{2 0 1 9}$ & $\begin{array}{c}\mathbf{6} \\
\text { months } \\
\mathbf{2 0 2 0}\end{array}$ & $\mathbf{2 0 1 8}$ & $\mathbf{2 0 1 9}$ & $\begin{array}{c}\text { 6 months } \\
\mathbf{2 0 2 0}\end{array}$ \\
\hline $\begin{array}{c}\text { Sberba } \\
\text { nk }\end{array}$ & $\begin{array}{c}12 \\
, 2\end{array}$ & 12,7 & 13,8 & 19,1 & 20,2 & 21,4 & 811,0 & 870,1 & 388,9 \\
\hline VTB & 10 & 10,9 & 11,8 & 14,2 & 14,7 & 15,4 & 178,8 & 201,2 & 41,9 \\
\hline $\begin{array}{c}\text { Gazpro } \\
\text { mbank }\end{array}$ & $\begin{array}{c}4, \\
8\end{array}$ & 4,9 & 5,4 & 4,2 & 4,5 & 4,8 & 39,5 & 33,8 & 28,3 \\
\hline $\begin{array}{c}\text { Alfa- } \\
\text { Bank }\end{array}$ & 0, & 1,3 & 1, & 2,1 & 2,3 & 2,6 & 44,9 & 51,1 & 102,8 \\
\hline $\begin{array}{c}\text { Russian } \\
\text { Agricul } \\
\text { tural } \\
\text { Bank }\end{array}$ & 0, & 1,1 & 1,3 & 2,1 & 2,2 & 2,5 & 2,1 & 4,3 & 3,2 \\
\hline
\end{tabular}

*compiled according to $[2,11]$

Table 2. Performance indicators of the largest Russian crowdfunding platforms for 2018-6 months of 2020

\begin{tabular}{|c|c|c|c|c|c|c|}
\hline $\begin{array}{c}\text { Crowdfun } \\
\text { ding } \\
\text { Platform }\end{array}$ & Year & $\begin{array}{c}\text { Total } \\
\text { Number of } \\
\text { Running } \\
\text { Projects }\end{array}$ & $\begin{array}{l}\text { Number of } \\
\text { Successful } \\
\text { Projects }\end{array}$ & $\begin{array}{c}\begin{array}{c}\text { Percentag } \\
\text { e of }\end{array} \\
\text { Successful } \\
\text { Projects, } \\
\%\end{array}$ & $\begin{array}{c}\text { Average } \\
\text { bill, } \\
\text { RUB }\end{array}$ & $\begin{array}{l}\text { Amount of } \\
\text { Funds } \\
\text { Raised, mln. } \\
\text { RUB. }\end{array}$ \\
\hline \multirow{3}{*}{ Penenza } & 2018 & 5389 & 2431 & 31 & 1,4 & 2000 \\
\hline & 2019 & 3708 & 1543 & 29 & 1,7 & 6000 \\
\hline & $\begin{array}{c}6 \text { months } \\
2020\end{array}$ & 11974 & 7685 & 51 & 3,3 & 26000 \\
\hline \multirow{3}{*}{ Planeta.ru } & 2018 & 2985 & 895 & 30 & 1,2 & 194 \\
\hline & 2019 & 3062 & 1010 & 33 & 1,4 & 628,7 \\
\hline & $\begin{array}{c}6 \text { months } \\
2020\end{array}$ & 9956 & 3063 & 31 & 2,6 & 1066,9 \\
\hline \multirow{3}{*}{$\begin{array}{l}\text { Boom- } \\
\text { starter }\end{array}$} & 2018 & 787 & 986 & 49 & 2 & 350 \\
\hline & 2019 & 947 & 312 & 33 & 1,6 & 308 \\
\hline & $\begin{array}{c}6 \text { months } \\
2020\end{array}$ & 3165 & 1699 & 34,2 & 3,6 & 799 \\
\hline \multirow{3}{*}{$\begin{array}{c}\text { TownMone } \\
\mathrm{y}\end{array}$} & 2018 & 1934 & 789 & 28 & 1,1 & 3062,9 \\
\hline & 2019 & 2148 & 676 & 32 & 1,3 & 3385,9 \\
\hline & $\begin{array}{c}6 \text { months } \\
2020\end{array}$ & 2775 & 1023 & 44 & 2,4 & 3800 \\
\hline \multirow{3}{*}{ StartTrack } & 2018 & 3654 & 1783 & 44 & 1,4 & 2485,7 \\
\hline & 2019 & 1976 & 645 & 34 & 1,7 & 2541,6 \\
\hline & $\begin{array}{c}6 \text { months } \\
2020\end{array}$ & 13165 & 3028 & 38 & 3,3 & 2957,0 \\
\hline
\end{tabular}

*(compiled according to [12-15]) 
As follows from the presented data, the crowdfunding method of financing innovative projects is not inferior to traditional financial intermediaries, but is only gaining momentum.

The largest players in the Russian crowdfunding market include the Penenza platform, which attracted investments totaling 26 billion rubles in 7685 business projects in 6 months of 2020. At the moment, the platform has 5,930 investors, 41,162 borrowers and published loans for $3,062,945,118$ rubles. The minimum amount for investors in a project with a volume of up to 1 million rubles is 50 thousand rubles, and in a project with a volume of 1 million rubles - 100 thousand rubles. The companies that most often receive investments are trade and services (79\% of the total number of companies)[12]. Using the same indicators, you can track the activity of the StartTrack platform: 7,839 investors, 86 companies attracted investments, and 2,957,772,060 rubles were attracted through StartTrack. The platform sets the minimum investment volume for project lending - 100 thousand rubles, and crowdinvestments start from 1 million rubles. The StartTrack platform offers companies "all available types of private financing", including loans, sale of shares in LLC, issue of shares or bonds [12].

Thus, the presented comparative performance indicators of traditional and alternative financial intermediaries indicate a breakthrough development of crowdfunding methods of financing that have revolutionized the field of financial intermediation, creating an alternative to outdated, inefficient, lost trust banking and replacing it with a software platform that is honest, transparent, efficient and creates less costs for borrowers and investors.

Taking into account the visible advantages, many banks create collaborations with crowd platforms. For credit institutions, crowdsourcing is an opportunity to diversify their business, reduce lending risks, and expand their customer base. To date, Russians have accumulated 27 trillion rubles on deposits in Russian banks [11], one part of which is inactive, and the other belongs to citizens with above-average incomes. It can be stated that at least $10 \%$ of them can direct their financial investments directly to business support. The market pioneer is Alfa-Potok, a crowdfunding platform from Alfa-Bank, which is an automated online service that allows individuals to invest money and lend to small businesses. There are also Moduldengi from Modul Bank, a platform where investors issue loans to companies for the execution of government contracts, Tochka JSC (Tochka Bank), a Multibank platform for entrepreneurs, and Simplifai LLC (SimplyFi), an online crowdfunding platform, launched a joint online crowdfunding service for entrepreneursclients of Tochka. Sberbank also launched its crowdfunding service in 2019, introducing its own investment platform - Sberkredo. Also, in 2019, another Bank, AK bars Bank, joined the crowdlending market [12]. Such platforms are primarily focused on attracting money from private investors. According to the Ministry of economic development, about $\$ 50$ billion is currently on Bank deposits, and it is more than realistic to attract at least $\$ 1$ billion to the crowdfunding market[22].An overview of Russian banking crowdfunding platforms is given in table 3 .

Table 3. Overview of Russian banking crowdfunding platforms

\begin{tabular}{|c|c|c|c|}
\hline Platform & $\begin{array}{c}\text { Year of Foundation, } \\
\text { Bank }\end{array}$ & $\begin{array}{c}\text { Amount of Funds } \\
\text { Raised, mln. RUB }\end{array}$ & $\begin{array}{c}\text { Mechanisms used to obtain } \\
\text { funding }\end{array}$ \\
\hline Alpha stream & $\begin{array}{c}2016 \\
\text { Alfa-Bank }\end{array}$ & 5000 & $\begin{array}{c}\text { Debt crowdfunding with no } \\
\text { choice of project }\end{array}$ \\
\hline $\begin{array}{c}2017 \\
\text { Module } \\
\text { Money }\end{array}$ & $\begin{array}{c}2018 \\
\text { Tochka Bank }\end{array}$ & 1898 & $\begin{array}{c}\text { Debt crowdfunding with no } \\
\text { choice of project }\end{array}$ \\
\hline SimplyFi & 1241 & $\begin{array}{c}\text { Debt crowdfunding with no } \\
\text { choice of project }\end{array}$ \\
\hline
\end{tabular}


Continuation of Table 3. Overview of Russian banking crowdfunding platforms

\begin{tabular}{|c|c|c|c|}
\hline Sbercredo & $\begin{array}{c}2019 \\
\text { Sberbank }\end{array}$ & No data & $\begin{array}{c}\text { Elective debt financing of } \\
\text { projects }\end{array}$ \\
\hline
\end{tabular}

*(compiled according to [11-15])

Today, one of the fastest growing crowdinvesting platforms in Russia is StartTrack. The minimum return for an investor on this platform is about $18 \%$, and the platform itself sets a Commission of 5-7\%. Thus, for the face. attracting investment, the total cost of resources attracted through the platform will be about $25 \%$. Approximately the same cost of attracted resources is noted on other sites. As for the volume of attracted resources, the undisputed leader is Alfa-stream (5 billion rubles), with the help of which about 90 thousand contracts were concluded. loan agreements and attracted 27 thousand customers. It should be noted that the actual data on the total amount of resources attracted by domestic crowdfunding platforms has already exceeded the forecast for 2020[15]

It should be noted that the development of krautblatter entails several important things for the market. One of them is the alignment of financial flows used by small and medium sized businesses. With limited access to Bank financing, entrepreneurs often go to the market for private shadow loans, sometimes take consumer loans or microloans at inflated rates and let the money into the business. Crowdfunding helps replace such non-targeted products with offers that are more optimized for the business. For example, in the case of contract activities, you can link the loan repayment schedule to the proceeds from the contract, which will avoid a cash gap. No less significant is the fact that crowdfunding platforms are becoming operators of credit bureaus. This is spelled out in the adopted Federal law No. 259-FZ of 02.08.2019[1].The above indicates that crowdfunding is an alternative form of raising funds. This technology should be developed in Russia on the basis of further digital transformation of the economy. This will allow you to accumulate temporarily free funds and provide them for the implementation of the goals and objectives of socio-economic development of the state.

\section{Conclusion}

Based on the data obtained, we can conclude that both banks and alternative financing methods play an important role in a sustainable economy and their positive impact on the development of the industrial sector of the economy. Thus, banks as traditional financial intermediaries through information technologies have been able to establish direct relationships between potential investors and borrowers interested in attracting investment in business projects, and minimize their risks by tracking the validity of payments and the volume of cash flows entering the borrower's current accounts, that is, to carry out so-called "equal lending".

In its turn, crowdfunding, being a new financial instrument, is primarily focused on small and medium-sized businesses, which are only growing every year and most of all need investment in one form or another. This is why investors ' money goes to the fastestgrowing, most important sector of the economy, which leads to such socio-economic effects as increasing and improving the effectiveness of innovative business projects and startups that affect GDP growth, the number of jobs, tax payments and the country's competitiveness as a whole. Thus, we can say that the development of financial intermediation will lead not only to the expansion of the financial sector of the economy, but also to its stabilization in general. 


\section{References}

1. On attractinginvestmentsusinginvestment platforms and on amendments to certain legislativeacts of the RussianFederation: Feder. Law of the RussianFederation of August 02, 2019 No. 259-FZ.

2. Banks and MFOs of Russia, https://www.bankodrom.ru

3. V.V. Drogichinskaya, A Practical Guide to Crowdfunding (2018)

4. I. A. Kalinina, K. S. Barmashov, Creative Economy, 11(12) (2017)

5. A. M. Kiyutsevskaya, Economic Issues, 4 (2019)

6. I.D.Kotlyarov, Manager, 11(3)(2020)

7. A.A. Kryukova, A.A. Sherstyankina, Karelian Scientific J., 6 (2(19)) (2017)

8. M.V. Leonov, Bulletin of SUSU. Series "Economics and Management", 9(4) (2015)

9. F. Mishkin, Economictheory of money, banking and financialmarkets(2006)

10. New instruments for attractingfinancing for the development of technologycompanies: practice of use and development prospects in Russia. Analytical report. https://ruscrowd.ru/

11. Official website of the Central Bank of the RussianFederation, https://www.cbr.ru/

12. Official website of the Association of Investment Platform Operators, https://ruscrowd.ru/

13. The official website of the crowdfunding platform Planeta.ru, https://planeta.ru/

14. The official website of the Boomstarter crowdfunding platform, https://boomstarter.ru/

15. Official website of the StartTrack crowdfunding platform, https://starttrack.ru

16. N.I.Parusimova, XI Intern. scientific-practical Conf., (St. Petersburg, 2019)

17. L.K. Plyusnina, Theory and Practice of Social Development, 6 (2017)

18. E.A. Pomogaeva, ANI: Economics and Management, 4 (25)(2018)

19. S. A. Potemkin, S. I. Chernykh, T.A. Larina, Regional Economy. South of Russia, 2(16) (2017)

20. J. Rich,Crowdfunding,Fundraising Reference Guide(2015)

21. Yu. Sergeeva, All Internet Statistics for 2020 - Figures and Trends in the World and in Russia(2020)

22. Will crowdfunding become an alternative to bankfinancing for small businesses. https://www.vedomosti.ru/

23. S. M. Frost,Banking Analyst'sHandbook: Money, Risks, and Professional Practices (2006)

24. 24. V.M. Usoskin, V.Yu. Belousov, I.O. Trump, Money and Credit, 5(2017)

25. J.S. Jr, Financial Management in Commercial Banking and the Financial Services Industry(2007)

26. S.V. Yakunin, A.V. Yakunina, Yu.V. Semernina, Bulletin of the Saratov State Social and EconomicUniversity, 2 (76), 121 (2019)

27. Amount of raisedfundsthrough crowdfunding in Russiain 2017 and 2019, https://www.statista.com/

28. E. F. Fama, Foundations of Finance(1976).

29. Crowdfunding in the Americas: USA, Canada, Latin America \& the Caribbean (2019)

30. J. Tobin, Commercial Banks asCreators of Money(1963) 